\title{
Factoring in the Complexity of the Cystic Fibrosis Lung to Understand Aspergillus fumigatus and Pseudomonas aeruginosa Interactions
}

\author{
Emily Beswick ${ }^{1,2} \mathbb{D}$, Jorge Amich ${ }^{1, *}$ and Sara Gago ${ }^{1, *(1)}$ \\ 1 Manchester Fungal Infection Group, Faculty of Biology, Medicine and Health, The University of Manchester, \\ Manchester Academic Health Science Centre, Core Technology Facility, Grafton Street, \\ Manchester M13 9NT, UK \\ 2 Academic Unit of Medical Education, Medical School, University of Sheffield, Beech Hill Road, Broomhall, \\ Sheffield S10 2TG, UK; efbeswick1@sheffield.ac.uk \\ * Correspondence: Jorge.amichelias@manchester.ac.uk (J.A.); Sara.gago-2@manchester.ac.uk (S.G.)
}

Received: 23 June 2020; Accepted: 4 August 2020; Published: 6 August 2020

check for

\begin{abstract}
Pseudomonas aeruginosa has long been established as the most prevalent respiratory pathogen in Cystic Fibrosis (CF) patients, with opportunistic infection causing profound morbidity and mortality. Recently, Aspergillus fumigatus has also been recognised as a key contributor to CF lung deterioration, being consistently associated with decreased lung function and worsened prognosis in these patients. As clinical evidence for the common occurrence of combined infection with these two pathogens increases, research into the mechanism and consequences of their interaction is becoming more relevant. Clinical evidence suggests a synergistic effect of combined infection, which translates into a poorer prognosis for the patients. In vitro results from the laboratory have identified a variety of possible synergistic and antagonistic interactions between A. fumigatus and P. aeruginosa. Here, we present a comprehensive overview of the complex environment of the CF lung and discuss how it needs to be considered to determine the exact molecular interactions that $A$. fumigatus and P. aeruginosa undergo during combined infection and their effects on the host.
\end{abstract}

Keywords: Aspergillus fumigatus; Pseudomonas aeruginosa; cystic fibrosis; combined infection

\section{Cystic Fibrosis}

Cystic fibrosis (CF) is a life-limiting, inherited autosomal recessive disorder resulting from the presence of one or more disease-causing mutations in the cystic fibrosis transmembrane conductance regulator (CFTR) gene. The global prevalence of CF is approximately 70,000-100,000 and within the United Kingdom (UK) alone, over 10,000 people are living with this disease [1,2]. The incidence of CF differs between geographical locations and ethnic groups; however, the highest rate is amongst Caucasian populations, especially those of northern European descent, in whom incidence is 1 in between 2500-4000 live births [1,3].

Since CF was first described over 80 years ago [4], patient life expectancy has vastly improved. In the 1950s, median life expectancy for a new-born diagnosed with CF was as little as several months and the main causes of death were meconium ileus or malnutrition due to pancreatic failure [5]. Life has dramatically improved for CF patients due to advances in modern medicine such as the development of mucolytic agents, specific anti-pseudomonal drugs, pancreatic enzyme replacement therapy as well as the introduction of a multi-disciplinary approach to CF patient care [5-7]. Yet despite these improvements, patients continue to deal with intensive treatment regimens and frequent hospitalisations that impact on their quality of life. Additionally, profound morbidity largely due 
to recurrent lung infections and progressive deterioration in lung function [8] makes progressive pulmonary disease resulting in fatal respiratory failure the main cause of death in CF patients [5,9].

The CFTR gene itself is located on the long arm of chromosome 7 at position 31.2 [10] and is subjected to a complex and strict transcriptional control that is not fully understood yet [11]. CFTR encodes a unique cyclic adenosine monophosphate (cAMP)-dependent ion channel, which is the only known member of the ATP-binding cassette superfamily that does not function as an active transporter [3]. The protein comprises five domains: (i) two pseudo-symmetrical membrane-spanning domains (MSDs) each made up of six helices connected by intra- and extra-cellular loops, (ii) two highly conserved nucleotide-binding domains (NBD1 and NBD2) and (iii) a regulatory domain characterised by charged residues and multiple consensus phosphorylation sites [12].

CFTR is located at the apical surface of epithelial cells, where it maintains ion transport across exocrine, endocrine and pulmonary epithelial interfaces [3]. CFTR regulates sodium [13,14], potassium [15-17], sodium bicarbonate [18], outward-rectifying chloride channels [19] and calcium-activated chloride channels [20,21]. CFTR also regulates ATP release, vesicle trafficking and cytokine expression [3].

More than 2000 variants of the CFTR gene have been identified [22], many of which are associated with causation of CF disease [5,23]. The majority of mutations identified in CFTR are localised to NBD1. Relatively few disease-causing mutations have been confirmed in NBD2 [24].

Mutations are classified into six groups according to their effect on protein expression and physiological function (Table 1) [25]. Although the mechanism and extent of depletion may differ, all classes of CFTR mutation result in overall functional loss of the protein in target cells [26].

Table 1. Classification of mutations in the cystic fibrosis transmembrane conductance regulator (CFTR) gene.

\begin{tabular}{|c|c|c|c|c|c|c|}
\hline & \multicolumn{6}{|c|}{ CFTR Mutation Class } \\
\hline CFTR Defect & $\begin{array}{l}\text { No functional } \\
\text { CFTR protein }\end{array}$ & $\begin{array}{c}\text { CFTR } \\
\text { trafficking } \\
\text { defect }\end{array}$ & $\begin{array}{l}\text { Defective } \\
\text { channel } \\
\text { regulation }\end{array}$ & $\begin{array}{c}\text { Decreased } \\
\text { channel } \\
\text { conductance }\end{array}$ & $\begin{array}{l}\text { Reduced CFTR } \\
\text { synthesis }\end{array}$ & $\begin{array}{c}\text { Decreased } \\
\text { CFTR } \\
\text { stability }\end{array}$ \\
\hline $\begin{array}{l}\text { Mutation } \\
\text { Type }\end{array}$ & $\begin{array}{c}\text { Nonsense; } \\
\text { frameshift; } \\
\text { canonical splice }\end{array}$ & $\begin{array}{l}\text { Missense; } \\
\text { amino acid } \\
\text { deletion }\end{array}$ & $\begin{array}{l}\text { Missense; } \\
\text { amino acid } \\
\text { change }\end{array}$ & $\begin{array}{l}\text { Missense; } \\
\text { amino acid } \\
\text { change }\end{array}$ & $\begin{array}{l}\text { Splicing defect; } \\
\text { missense }\end{array}$ & $\begin{array}{c}\text { Missense; } \\
\text { amino acid } \\
\text { change }\end{array}$ \\
\hline \multirow{2}{*}{$\begin{array}{l}\text { Examples of } \\
\text { Causative } \\
\text { Mutation }\end{array}$} & G542X & $\Delta \mathrm{F} 508$ & G551D & $\mathrm{R} 117 \mathrm{H}$ & $3849+10 \mathrm{kbC} \rightarrow \mathrm{T}$ & 4326delTC \\
\hline & W1282X & N1303K & D178R & R347P & $2789+5 \mathrm{G} \rightarrow \mathrm{A}$ & G1412X \\
\hline
\end{tabular}

The most common CF-causing mutation is a class II mutation resulting in deletion of phenylalanine at amino acid $508(\Delta \mathrm{F} 508)$. Up to $90 \%$ of CF patients are homozygous for $\Delta \mathrm{F} 508$ and this deletion constitutes up to two-thirds of mutated alleles in northern Europe and North America [27,28]. F508 is located in a highly conserved, alpha-helical region (residues 495-565) in NBD1 [29]. Deletion disrupts ATP-dependent interactions in the F1-ATPase domain of NBD1 and alters kinetic and thermal properties $[12,30]$. These changes affect protein assembly and post-translational stability such that maturation of core glycosylated $\mathrm{CFTR}^{\Delta \mathrm{F} 508}$ to complex glycosylated fails, leading to endoplasmic retention of $C F T R^{\triangle F 508}$ [31]. As a result, $\mathrm{CFTR}^{\triangle \mathrm{F} 508}$ is never trafficked to the cell membrane and the concentration of functional CFTR in target cells is minimal.

\section{Clinical Manifestations of Cystic Fibrosis}

Functional loss of the CFTR ion channel leads to an inability to maintain osmotic balance across all epithelial surfaces, resulting in wide-ranging pathophysiological effects that cause multi-system organ dysfunction [32]. Extra-pulmonary manifestations of mutant CFTR are intestinal obstruction (including meconium ileus in new-borns), exocrine pancreatic insufficiency, biliary cirrhosis of the liver, 
abnormal growth and infertility in males [33,34]. In the long-term, patients may develop cystic-fibrosis related diabetes mellitus [35] and are at increased risk of clinical depression and anxiety [34]. However, the major pathological consequence of $\mathrm{CF}$ is chronic lung disease.

Despite the monogenic nature of CF disease, it is likely that clinical manifestations are the product of multiple pathophysiological changes [36]. This new appreciation of CF as a multi-factorial disease may also explain the failure of mucolytic agents or aerosolised bicarbonate alone to rescue disease status in animal models, as addressing a singular aspect of the pathology is insufficient for cure $[1,5,37]$. There are two main hypotheses proposed to explain the pathogenesis of CF lung, the "low-volume hypothesis" and the "pH hypothesis".

The "low-volume hypothesis" is the most well-established theory for the pathogenesis of CF pulmonary disease [33]. This hypothesis stipulates that in CF lungs, loss of chloride efflux and excess sodium and water reabsorption causes dehydration of both the airways surface liquid (ASL) and mucus secretions. Cilia are rapidly compressed by the mucus layer [27], resulting in pulmonary ciliary dyskinesis and impaired mucociliary clearance [3]. Thus, stagnant mucus plaques form in CF airways, providing microaerobic and even anaerobic conditions that facilitate colonisation and persistence of various fungal and bacterial pathogens, notably P. aeruginosa [38].

An alternative hypothesis is based upon alteration of the ASL pH: loss of function in CFTR impairs bicarbonate transport across the pulmonary epithelia and reduces the ASL pH [39]. This directly inhibits the innate antimicrobial activity of the many antimicrobial molecules contained in ASL including lactoferrin, lysozyme, beta-defensins, LL-37, secretory leukocyte peptidase inhibitor and surfactant protein A and D [40]. This hypothesis is supported by investigations in a porcine model, where it was shown that both the individual and synergistic activities of these antimicrobial molecules were significantly reduced in CF piglets, compared to wild type [39]. Furthermore, administration of aerosolised sodium bicarbonate to increase ASL $\mathrm{pH}$ was found to rescue bacterial permeabilisation and killing mechanisms in CF pigs [39]. Elimination of CFTR-regulated bicarbonate secretion lowers not only ASL $\mathrm{pH}$, but the $\mathrm{pH}$ of the submucosal glands also [41]. Submucosal glands produce mucus strands that detach from the epithelium and comprise the mucus layer. Lack of mucus strand detachment thus contributes to abnormal mucus composition, impaired mucociliary transport and the obstruction of small airways [42,43].

In addition to defects in airway epithelium, mutant CFTR also gives rise to immune system defects in CF airways. In particular, the role of the neutrophil is well characterised, with neutrophil-mediated inflammation identified as a key driver of lung damage in CF [44]. Chronic colonisation continuously activates pathogen recognition receptors, causing excessive influx of polymorphonuclear neutrophils (PMNs) into the lungs [33]. However, mutant CFTR impairs degranulation and phagocytosis, so neutrophils cannot kill pathogens effectively. Neutrophils also have enhanced lifespan in CF due to dysregulation of apoptotic pathways and accumulate within the airways causing oxidative stress, which further activates inflammatory pathways and IL-8-mediated PMN recruitment [45]. Neutrophils also release elastase, a powerful serine protease that drives bronchiectasis by digesting cellular elastin and secondly, increases mucus production by cleavage of epithelial cell-surface sodium channels [46]. The result is reduced pathogen clearance, chronic inflammation and damage to lung tissue [33].

The host response to infection is compromised in CF; however, abnormally elevated levels of the pro-inflammatory cytokines IL-6, IL-1 $\beta$, IL- 8 and TNF $\alpha$ have also been found in uninfected CF immortalised cell lines and ex vivo lung explants $[27,47,48]$. These findings have led to the hypothesis that mutated CFTR also makes epithelial cells intrinsically more inflammatory, and that the primary defect in CF may be a dysregulated host inflammatory response [27]. In addition, the production of anti-inflammatory substances like IL-10, docosahexaenoic acid and lipoxin $[49,50]$ is reduced in $\mathrm{CF}$, resulting in a cytokine imbalance that favours a pro-inflammatory lung environment $[8,51]$. Indeed, T helper cell type (Th)-2, Th-17 and T-regulatory cell responses are also dysregulated at numerous levels [52]. A plausible interpretation of these findings by Elborn (2016), is that intrinsic pro-inflammatory cell properties may $\mathrm{b}$ the primary cause of inflammation in the $\mathrm{CF}$ lung during 
infancy; however exposure to pathogenic microorganisms and ineffective immune response becomes the main driver of chronic inflammation in later life [5].

In consideration of the evidence, the CF lung may be described as a pro-inflammatory environment characterised by viscous mucus secretions, acidic ASL pH, and impaired innate and adaptive immune responses to pathogen challenge. Overall, these pathophysiological changes contribute to the formation of a permissive pulmonary niche, facilitating chronic lung colonisation with opportunistic microorganisms. Thus, CF patients are vulnerable to recurrent cycles of infection and inflammation, inevitably leading to pulmonary system failure [53].

\section{Dysbiosis of the Pulmonary Microbiome in Cystic Fibrosis}

The lung was, until recently, thought to be a sterile organ (unless infected). Previously, standard microbial culture failed to replicate the environment inside the lung sufficiently to enable bacterial growth from bronchoalveolar lavage (BAL) samples, perpetuating the sterile lung theory. The advent of molecular techniques has since generated evidence to demonstrate that healthy lungs are colonised by a distinct bacterial community [54], which is putatively implicated in the pathology of chronic lung diseases like CF [55].

In a healthy host, the most prevalent phyla are Firmicutes and Bacteroidetes [54] with lesser numbers of Proteobacteria and Actinobacteria also present [56]. The core pulmonary microbiota comprises: Pseudomonas, Streptococcus, Haemophilus, Neisseria, Prevotella, Fusobacterium and Veillonella species [57]. Growth conditions in the lung are determined by nutrient and oxygen availability, $\mathrm{pH}$, temperature, as well as the host inflammatory response. In health, these three factors are tightly regulated, but in patients with chronic lung diseases like $\mathrm{CF}$, they are imbalanced by compromise of host defences [54]. Research undertaken to characterise the microbiota in chronic lung diseases has identified aberrant outgrowth of one of the four main phyla [56] leading to dysbiosis of the microbiome. For CF, Proteobacteria and Actinobacteria are overrepresented, correlating with clinical evidence of bacterial infections that predominate in these patients [56,58].

CF lung pathogens are typically opportunistic, environmental bacteria and fungi that rarely cause disease in healthy hosts. As discussed above, CF patients fail to clear invading bacteria and fungi, which facilitates chronic infection. Chronic colonisation and infection results in the production of microbial toxins, proteases and invasive growth, e.g., fungal hyphae, which causes inflammation, epithelial tissue damage and overall decline in pulmonary function. Microbial growth within the lung also triggers pro-inflammatory pathways and leukocyte recruitment, which further damages the epithelia and induces secretion of viscous mucus [33]. The respiratory "virome" remains largely unknown $[59,60]$. Few studies have investigated the contribution of viruses to the CF lung metagenome, mainly due to the current lack of consensual viral gene markers comparable to the $16 \mathrm{~S}$ ribosomal system in bacteria [61,62]. Despite this incomplete picture, it remains that disease course and severity is increased when CF patients contract viral pneumonias [63].

The CF microbiome is dynamic and undergoes compositional changes as pulmonary disease progresses. However, relating these to pulmonary exacerbations has proved challenging [59]. Cross-sectional and longitudinal studies have demonstrated that CF patients are colonised by increasing numbers of microorganisms as they age, with good airway diversity typically maintained until adolescence [59]. The most common microorganism found in the airways of CF children is Staphylococcus aureus, which is substituted for by P. aeruginosa as patients transition to adulthood $[2,64,65]$. The relationship between these two pathogens is not yet understood, but some clinical studies have indirectly supported an inverse association between them [66,67]. However, it seems to be clear that the development of chronic infections caused by P. aeruginosa are associated with lung function decline and thus treatments aiming to eradicate initial infections are often recommended [68-70]. However, the administration of cumulative antibiotic courses to treat recurrent lung infection introduces selective pressure that favours survival of resistant bacteria $[59,71]$. 
Data from both the UK and US 2018 Cystic Fibrosis Trust patient registry reports $[2,65]$ show that $P$. aeruginosa overall remains the most prevalent pathogen colonising CF lungs due to its capacity to specifically adapt to the CF airway and grow as biofilm, discussed in detail in the next section. Other important pathogens known to colonise and cause infection in CF patients include: Haemophilus influenzae, S. aureus and meticillin-resistant S. aureus, Stenotrophomonas maltophilia, the Burkholderia cepacia complex [59] and atypical non-tuberculous Mycobacteria species [72]. Anaerobes are also abundant in CF sputum and BAL samples [73], however their contribution to pulmonary morbidity remains unclear [68]. Anaerobes likely contribute to the "resistome" (the total number of antibiotic-resistance genes carried by microorganisms in the lungs) but whether their overall effect is beneficial, or detrimental remains to be deciphered $[73,74]$.

Finally, the CF mycobiome has recently emerged as a promising area of research. Previously, the mycobiome was under-recognised due to the low sensitivity of culture-based detection methods, combined with low overall numbers of fungi in the lungs (in comparison to bacteria) and the general perception of these as environmental contaminants [75,76]. In fact, the CF mycobiome is fairly diverse: Aspergillus, Candida, Cladosporium, Penicillium, Scedosporium and Exophiala species have all been identified in CF cohorts [77,78]. The contribution of A. fumigatus to pulmonary disease in CF is of particular interest, as this pathogenic fungus is frequently isolated from patient respiratory samples and has been associated with worsened prognosis and pulmonary function [79].

Herein, the individual contribution of $P$. aeruginosa and $A$. fumigatus to CF lung disease will be discussed, before reviewing the current state of the field regarding combined infection with these two classic CF pathogens.

\section{Pseudomonas aeruginosa Is the Predominant Respiratory Bacterial Pathogen in Cystic Fibrosis}

P. aeruginosa is a Gram-negative bacterium and facultative anaerobe, found ubiquitously in soil and water. P. aeruginosa is a prolific pathogen that infects many different tissues, causing serious skin and soft tissue infections; endocarditis; urinary tract infections; gastrointestinal infections; meningitis; ocular and ear infections; and ventilator-associated pneumonias [33]. P. aeruginosa causes both chronic and acute infections, the majority of which occur in the immunocompromised, hospitalised patients or those with an underlying pulmonary disease, like CF.

P. aeruginosa has long been established as a formidable, opportunistic pathogen in CF patients, with up to $80 \%$ of individuals chronically colonised by age 20 [80]. The contribution of this bacterium to progressive lung disease in $\mathrm{CF}$ is so profound, that $P$. aeruginosa colonisation status remains the single most important determinant of morbidity and mortality in CF [3]. Despite intensive antibiotic therapy and the development of drugs with enhanced anti-pseudomonal activity, the vast majority of CF patients that experience intermittent infection with P. aeruginosa will go on to establish chronic infection (defined as infection for $>6$ months + --positive serology) [81].

Patients are periodically colonised by phylogenetically distinct strains of P. aeruginosa from early on in life and longitudinal studies have demonstrated that by age three, $98 \%$ of CF patients have positive serology and/or culture for P. aeruginosa [81,82]. During this intermittent stage, infection is caused by planktonic $P$. aeruginosa cells and may still be successfully eradicated by inhaled antibiotic therapy [81]. Transition from intermittent to chronic infection represents successful adaption of the bacterium to CF airways, and is a seminal clinical event that precipitates pulmonary decline and increased mortality [83].

Adherence to the lung epithelium is mediated by P. aeruginosa flagella and pili [33]. Once P. aeruginosa has colonised the epithelium, diffusible LasR and RhiR quorum sensing molecules regulate the expression of immunomodulatory virulence factors to facilitate survival in the hyperinflammatory, neutrophil-rich CF lung [84]. For example, P. aeruginosa secretes exotoxins via its Type III secretion system that can directly lyse neutrophils [85], pyocyanin induces neutrophil apoptosis [86] and alkaline protease degrades complement proteins to evade opsonophagocytosis [87]. 
Crucially, P. aeruginosa possesses a highly plastic genome that undergoes micro-evolution within the host, allowing specific adaption to the CF niche and rapid acquisition of gene elements encoding multi-drug resistance determinants [3]. Evolution is driven by the uniquely stressful environment that $P$. aeruginosa encounters in CF lungs, for example high antimicrobial drug concentration and neutrophil abundance [33]. Micro-evolutions arise by spontaneous mutation and subsequent selection of phenotypic/genotypic variants with enhanced survival [88]. The emergence of variants within an infected individual facilitates transition to chronic infection [89]. Common variant characteristics include downregulation of immunostimulatory virulence factors [90], overexpression of exopolysaccharides [81] and decreased motility to promote biofilm formation [91-94]. In fact, biofilm development is characteristic of chronic infections, which are virtually impossible to eradicate as biofilms confer increased resistance to antimicrobials and immune killing $[95,96]$. One of the most significant variants that has been associated with biofilm formation and establishment of chronic infection is the emergence of mucoid colonies [91]. Furthermore, mucoid colonies are strongly associated with severe bronchiectasis and rapid respiratory decline in CF patients [97]. Mutations in the $m u c A$ gene give rise to this phenotype, which overexpresses alginate exopolysaccharide. Mucoidy can inhibit complement activation [98]; is resistant to neutrophil extracellular traps [99]; evades phagocytic killing [100]; resist innate antimicrobial peptides including LL-37 [101]; and is recalcitrant to even specifically anti-pseudomonal drugs [33,102].

\section{Aspergillus fumigatus Is the Predominant Respiratory Mould Pathogen in Cystic Fibrosis}

Aspergilli are filamentous, saprophytic fungi that decompose organic matter and are integral to the recycling of carbon and nitrogen compounds in numerous environmental niches [103]. Various characteristics allow Aspergillus species to survive within physiologically harsh environments, including rapid germination, growth within a wide $\mathrm{pH}$ range and at high temperatures $\left(<60^{\circ} \mathrm{C}\right)$ and flexible nutrient metabolism [104]. Aspergilli are therefore found worldwide in soil, decaying vegetation and ambient air as well as in artificial environments such as composting facilities, air handling systems and building insulation $[103,105]$. Human exposure to these ubiquitous fungi is inescapable; however, colonisation, infection and disease only occurs if host defences fail to eradicate fungal fragments or spores (conidia) from the body [106]. Disease is therefore a product of complex interplay between fungal virulence factors and host-related factors such as immune status and pulmonary structure $[107,108]$.

The highest burden of aspergillosis is within the pulmonary system [109] because exposure to infectious particles most frequently occurs via inhalation of airborne conidia, fungal allergens or other cell fragments. Aspergillus sporulate abundantly and a single colony can generate several billion conidia, which are then disseminated by air and other routes [110]. Humans inhale many litres of air every minute, resulting in constant exposure to thousands of airborne conidia $[106,111]$. Thus, respiratory forms of aspergillosis are prevalent in the global population: chronic pulmonary aspergillosis affects 3 million people; fungal allergy including sensitisation over 10 million; and invasive diseases affect 0.2 million $[106,109]$.

A. fumigatus is the most pathogenic species within the genus as a whole, although A. flavus, A. nidulans, A. niger, and $A$. terreus are capable of causing disease in humans [110]. In addition, A. fumigatus is associated with highest morbidity in CF patients [75]. The success of A. fumigatus as a respiratory pathogen is multifactorial; however, a critical factor is that its spores are small enough (2-3 $\mu \mathrm{m}$ diameter) to penetrate deep into the lungs and reach the distal alveoli $[110,112]$.

Aspergillosis rarely affects healthy hosts because deposited spores are rapidly eradicated by innate defences. The first line of defence is the lung epithelium itself, where inhaled conidia and fungal fragments encounter mucopolysaccharide secretions in the upper respiratory tract that effectively trap and clear conidia via the mucociliary pathway. However, Aspergillus spores penetrating as far as the alveoli bypass this defence mechanism. Specialised epithelial cells also secrete antimicrobial molecules and recruit immune cells to the deposition site [106]. In order for invading pathogens to be cleared efficiently, lung epithelial cells, macrophages and dendritic cells maintain the balance between Th-1, 
Th-17, Th-2 and T-regulatory cells. Th- 1 cell proliferation is critical in responding to fungal challenge as this pathway activates neutrophils, T-cells and macrophages, which phagocytose fungal cells [106,112]. The role of neutrophils in A. fumigatus challenge is well defined; these cells phagocytose conidia [110] and employ extracellular traps (NETs) to inhibit hyphal growth too large for phagocytosis [113].

In CF, these innate host defences are impaired and Aspergillus conidia germinate. Pulmonary aspergillosis may manifest as four distinct disease entities in CF patients: chronic colonisation, Aspergillus hypersensitisation, allergic bronchopulmonary aspergillosis (ABPA) or Aspergillus bronchitis [79]. Two different models have been proposed to explain development of aspergillosis in $\mathrm{CF}$, each supported by limited clinical research. The first proposes sequential disease progression with increasing severity, for example developing Aspergillus bronchitis subsequent to persistent colonisation, whereas the other considers each disease entity to be separate [79].

Aspergillus colonisation prevalence in CF patients is between 10-57\%, with higher prevalence being associated with increasing age and poorer lung function [79]. Colonisation occurs when Aspergillus spores germinate and form mycelium at the epithelial surface [76]. The pathophysiology of progression from colonisation to active pulmonary infection has not yet been fully determined, however, chronic colonisation is a predecessor to pulmonary aspergillosis in compromised hosts [106,107].

Bronchial colonisation with A. fumigatus certainly drives the development of allergic forms of aspergillosis [76,114]. Aspergillus hypersensitisation is characterised by a raised immunoglobulin $\mathrm{E}$ response to Aspergillus allergens without clinical symptoms [76,107]. Baxter et al. (2013) also showed that hypersensitisation is distinguishable from ABPA by negative galactomannan test and lack of raised serum IgG [115].

ABPA is now a well-defined clinical entity in CF patients, despite challenges in the field regarding standardisation of diagnostic criteria [116]. This allergic aspergillosis is characterised by an exaggerated Th2-mediated immunoglobulin E response to Aspergillus allergens, with eosinophilia and mast cell degranulation [76,107]. Prevalence of ABPA in CF patients varies between 1-18\% depending on geographical region but is likely to be underdiagnosed [79]. Classic manifestations of ABPA are respiratory exacerbation (wheeze), positive serology against Aspergillus (IgE) and visible pulmonary infiltrates upon imaging [117].

Aspergillus bronchitis is an emerging form of clinical aspergillosis in CF patients, affecting approximately $9 \%$ of this cohort [118]. Pseudomembranous mycelial growth in the airways causes breathlessness, recurrent respiratory infections (that respond poorly to antibiotics) and mucus plugging. Bronchoscopic examination typically reveals bronchial erythema, ulceration and superficial hyphal invasion of the mucosa $[106,119]$.

The contribution of A. fumigatus to chronic pulmonary disease in CF is now clear and well-recognised. Advances in next-generation sequencing and culture-independent techniques have made the study of diverse microbial communities possible. Now, inter-kingdom interactions between A. fumigatus and dominant bacterial pathogens like P. aeruginosa have become established as a promising area of research due to their clinical implications.

\section{Combined Infection with Aspergillus fumigatus and Pseudomonas aeruginosa in Cystic Fibrosis}

A. fumigatus and P. aeruginosa are the most prevalent fungal and bacterial species that infect CF airways, respectively [120]. P. aeruginosa has long been recognised as a key pathogenic member of the CF lung microbiota; however, until recently, the contribution of $A$. fumigatus to pulmonary disease in $\mathrm{CF}$ was underestimated. Application of molecular techniques such as next-generation sequencing has facilitated characterisation of the complex microbial community that colonises CF lungs, bringing about a paradigm shift in the management of polymicrobial lung infections in this patient cohort [83].

Clinical evidence has for some time suggested high frequency of A. fumigatus-P. aeruginosa combined infection in CF patients. Both pathogens have been isolated simultaneously from patient sputum samples, with $A$. fumigatus identified in up to $60 \%$ of patients with chronic P. aeruginosa and conversely, P. aeruginosa identified in up to $64.2 \%$ of patients positive for A. fumigatus [121,122]. Indeed, 
it has been reported that $P$. aeruginosa infection is associated with higher incidence of concurrent and subsequent $A$. fumigatus infection [123], and that $A$. fumigatus colonisation was associated with an increased risk of $P$. aeruginosa colonisation [124]. A recent systematic review and meta-analysis estimated pooled combined infection prevalence to be $\sim 15.8 \%$, with a range of $2.2-44.8 \%$ [120]. For these patients, persistent combined infection with $A$. fumigatus and P. aeruginosa is associated with overall worsened lung function [125]. Unfortunately, studies investigating clinical manifestations of A. fumigatus-P. aeruginosa combined infection in CF patients are limited and prospective longitudinal studies are required in order to confirm these associations [83].

In vitro studies have mostly described antagonistic interactions between these two pathogens. For example, $P$. aeruginosa is known to inhibit $A$. fumigatus through the action of several secreted molecules: secretion of dirhamnolipids inhibit growth by blocking $\beta 1,3$ glucan synthase [126], homoserine lactones suppress hyphal growth [127] and reactive oxygen species (ROS)-producing phenazine compounds cause fungal death [128]. Although paradoxically, promotion of $A$. fumigatus by $P$. aeruginosa also occurs through phenazine secretion, whereby sub-bacteriostatic concentrations of phenazine induce iron uptake by A. fumigatus [126,129]. P. aeruginosa also mediates A. fumigatus growth inhibition by iron starvation through various mechanisms including iron chelation by pyoverdine [130,131] and pyocheline (a compound that also triggers ROS production) [132]. In addition, the Pf4 class of bacteriophages produced by P. aeruginosa are known to bind to and inhibit the metabolic activity of $A$. fumigatus biofilms [133]. With regards to A. fumigatus inhibition of $P$. aeruginosa, the main inhibitory agent secreted by the fungus is gliotoxin, which is a broad-spectrum inhibitor of bacterial biofilm formation [134]. Synergistic interactions have also been described in vitro; for example, $P$. aeruginosa can indirectly stimulate the growth of $A$. fumigatus by release of a volatile organic compound, dimethyl sulphide, demonstrating that $A$. fumigatus and $P$. aeruginosa interact even at distance [135]. Additionally, it has been described that the A. fumigatus stress response to pseudomonal phenazines can degrade those molecules into chemicals that induce Aspergillus siderophore and enhance fungal iron scavenging [136,137]. A. fumigatus response to iron is also modulated by a pseudomonal quorum sensing molecule, P. aeruginosa quinolone signal, which enhances fungal growth and metabolism under iron-rich conditions, similar to those found in the CF lung environment [138]. Conversely, recent proteomic analysis by Margalit et al. has shown that A. fumigatus can confer fitness to $P$. aeruginosa by increasing environmental nutrient availability, especially of amino acids and nitrate, which thereby stimulates bacterial growth and pathogenicity [139]. The nature of A. fumigatus-P. aeruginosa interactions becomes more complicated when other factors are considered. For instance, the inhibitory effect of $P$. aeruginosa on $A$. fumigatus is reduced under hypoxia, which is the actual environment where these pathogens interact [140]. Furthermore, small colony variants of $P$. aeruginosa with high-level pyoverdine expression (mucoidy phenotype), which are commonly isolated from chronically colonised CF lungs, have been shown to be more inhibitory towards A. fumigatus [141]. Inhibitory capacity is also determined by mode of growth, as P. aeruginosa is more inhibitory towards $A$. fumigatus in biofilm form, compared to planktonic [129] Moreover, P. aeruginosa is more inhibitory when growing as a biofilm compared to planktonic, but is only weakly inhibitory towards mature A. fumigatus biofilms [142]. In context, the majority of CF patients are chronically colonised by P. aeruginosa prior to A. fumigatus and therefore interactions would most likely occur between pre-formed P. aeruginosa biofilm and desegregated hyphal, rather than thick mycelial, fungal growth [129].

In vitro results reflect that both synergistic and antagonistic interactions are possible between $P$. aeruginosa and $A$. fumigatus. Differences in the type of interaction detected in some of the studies described above, is likely due to the experimental set up and methodology. For example, interactions will be dependent on the medium used to grow the microorganisms, as the nutrient environment strongly influences the production of metabolites that can exert an effect on the other microbe (e.g., the siderophores, pyoverdine and pyochelin, are produced only under iron limiting conditions). In any case, both synergistic and antagonistic interactions may have a deleterious effect on the host. Herein, synergism can cause increased pathogen growth and antagonism can result in increased 
damage to host tissues due to production of toxic molecules. An important first step to clarify the specific relationship that $A$. fumigatus and P. aeruginosa establish in the human lung, would be to consider the contribution of the host and host-pathogen interactions. Thus far, only a handful of studies have investigated the pathogen-pathogen interaction including either host cells or an in vivo model. Reece et al. reported a mutually antagonistic effect that may increase the pro-inflammatory response in CF epithelial cells and resulted in P. aeruginosa causing increased mortality in Galleria mellonella after pre-exposure to a non-lethal dose of A. fumigatus [134]. Similarly, we recently described that combined infection triggered increased fungal and bacterial burdens and caused greater mortality in G. mellonella [143]. Margalit and colleagues showed that A. fumigatus renders human alveolar epithelial cells unable to internalise P. aeruginosa, which resulted in higher proliferation of the bacteria in combined infection, compared to in single infection [144]. In addition, Briard et al. found that sequential infection of monocytes by $P$. aeruginosa and A. fumigatus synergistically increased the secretion of the pro-inflammatory cytokine IL1 $\beta$, which could cause an over-inflammatory environment in patients with combined infection [132]. Finally, Smith et al. have reported that $P$. aeruginosa production of cytotoxic elastase is enhanced in the presence of $A$. fumigatus, which caused more damage to epithelial cells [145]. Overall, these studies suggest that combined infection causes greater damage to the host tissues, independent of the sequence of infection.

In summary, it will only be possible to determine the real nature and exact interactions that A. fumigatus and P. aeruginosa undergo during combined infection, when the complexity of the CF lung is factored into experimental design. For this purpose, animal models seem key; however, to date, only two studies have attempted to model pulmonary combined infection in mice, with limited results. The first modelled combined infection by chronically infecting corticosteroid-treated mice with A. fumigatus using agar beads embedded with conidia, then twelve days later superinfecting those mice with P. aeruginosa [146]. In these superinfected mice, Yonezawa et al. found no change in fungal burden and increased bacterial burden, with statistical analysis showing a non-significant decrease in mortality compared to single A. fumigatus-infected mice [146]. These results diverge from the current understanding amongst clinicians, which is that combined infection increases patient mortality. In fact, the scope and findings of this study were limited by its methodology in several different aspects. Firstly, the reverse sequence of $A$. fumigatus superinfection on top of chronic P. aeruginosa infection was not assessed, despite the majority of CF patients being chronically colonised by P. aeruginosa prior to A. fumigatus [129]. Secondly, the inoculation of conidia embedded into potato dextrose agar beads does not represent a natural infection process, as fungal metabolism is affected by the rich medium, and thus methodology may have led to artefactual interactions in this model. Finally, corticosteroid treatment is not an adequate method for modelling chronic lung inflammation in mice.

The same group attempted to assess combined infection and evaluate antimicrobial drug efficacy in vivo using an alternative methodology [147]. In this study, mice were simultaneously inoculated by nasal administration with an A. fumigatus conidial suspension and P. aeruginosa cell suspension. Unfortunately, the use of a leukopenic model resulted in combined infected mice dying within three days post-infection, which impeded any assessment of the A. fumigatu-P. aeruginosa interaction [147]. These two studies highlight the technical problems currently encountered in an in vivo combined infection model, where animals face high pathogen challenge and experimental design is complicated.

In conclusion, the complexity of described interactions between these two pathogens indicates that the nature of their relationship, as well as their combined effects on the host, is strongly dependent on the specific conditions in which they are found. The CF lung is extremely complex and therefore, this unique environment needs to be factored in to be able to determine the exact interactions that $P$. aeruginosa and $A$. fumigatus undergo during combined infection.

\section{Future Directions for Clarifying A. fumigatus-P. aeruginosa Interactions in CF}

We believe that the variety of findings described above (Figure 1) are a product of the broad range of models used thus far to assess A. fumigatus-P. aeruginosa interactions. Hence, this field requires 
further and more focused investigations to gain a more complete and accurate understanding of in vivo interactions. In the future, employing experimental models such as air-liquid interface culture of human CF bronchial epithelial cells, with isogenic CF cell lines carrying specific mutations, $\mathrm{CF}$ transgenic mice or primary lung cells from patients with known CFTR mutations will improve the representation of the unique environment in which A. fumigatus and P. aeruginosa encounter each other during combined infection of the CF lung. Indeed, the complexity of the CF lung environment will require careful consideration during experimental design. For example, $\mathrm{CF}$ is characterised by progressive pulmonary deterioration and it must therefore be acknowledged that the lung environment colonised by A. fumigatus and P. aeruginosa changes over the disease course. In addition, antimicrobial treatment prescribed to CF patients is now known to impact not only the target organism, but the microbial community as a whole, which has important implications in the context of combined infection [129]. For example, Baxter et al. (2013) reported that treating respiratory exacerbations in CF patients with short-term courses of anti-Pseudomonal drugs reduced Aspergillus species abundance, indicating an inter-dependent relationship between the two species [115]. Furthermore, it is well established that $P$. aeruginosa undergoes micro-evolutions within the $\mathrm{CF}$ lung to adapt to the challenging environment [88] and these resultant strains seem to interact differently with A. fumigatus [142,148].

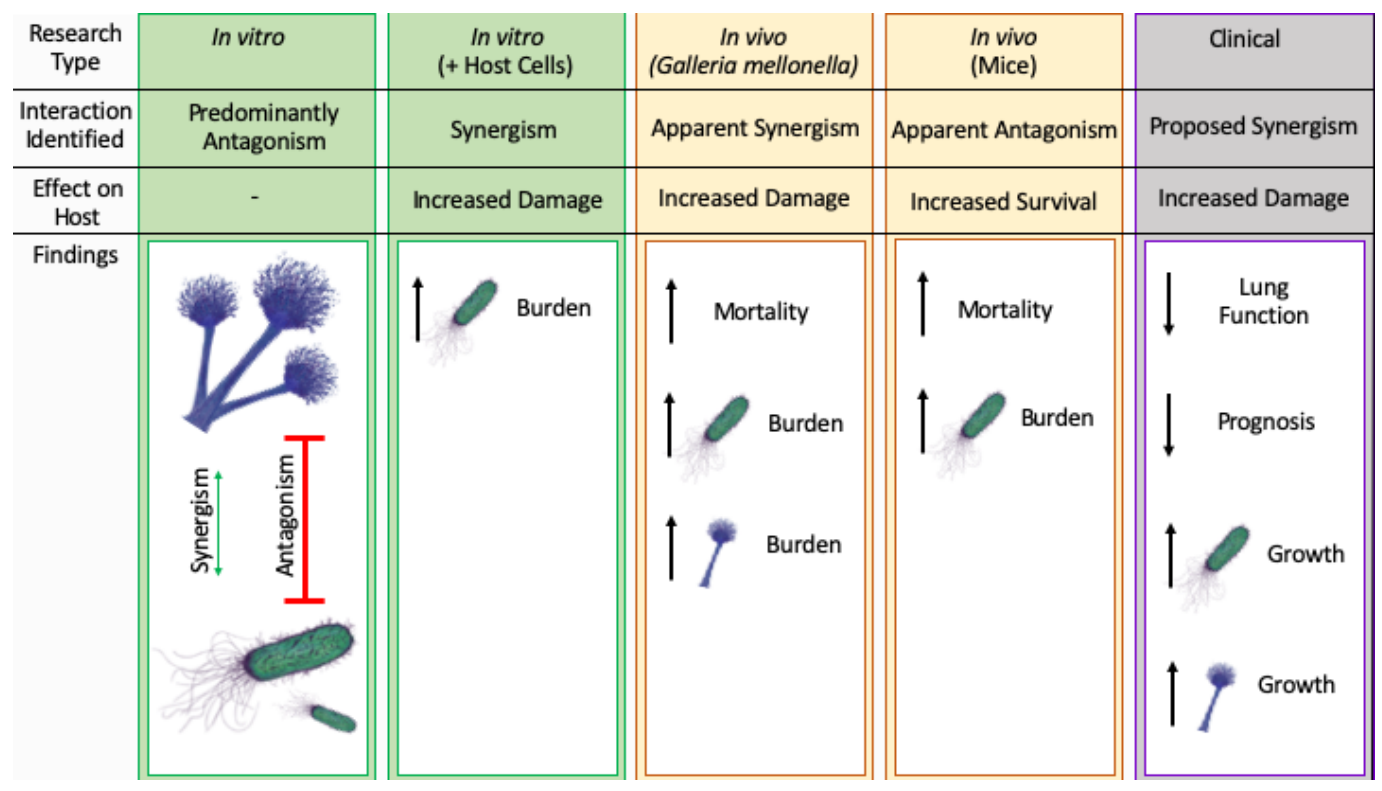

Figure 1. Pseudomonas aeruginosa-Aspergillus fumigatus interactions identified in different models of combined infection. The figure summarises the type of interaction and the main effects observed in published studies to-date, which are divided based on the level of complexity of the model. In vitro studies have detected predominantly antagonistic interactions of one pathogen on the other (red arrow), but a few have also described synergistic interactions (green arrows). All other models have detected increased (black arrows) pathogen burden and/or mortality and clinical studies have detected decreased lung function.

Upon consideration of all the findings, our interpretation is that the nature of A. fumigatus- $P$. aeruginosa interactions is variable, and likely dependent upon environmental factors relating to disease progression and treatment. Similarly, Zhao et al. (2018) suggested that interactions between A. fumigatus and $P$. aeruginosa might shift from a synergistic growth pattern, to mutual inhibition as CF lung disease progresses [120]. Initially, P. aeruginosa colonisation and growth as biofilm gives rise to nutritional and immunological conditions that promote concurrent growth of A. fumigatus. For an undefined period, the two microorganisms grow in a synergistic manner, although competition for biological resources may shift the balance towards mutual inhibition, which can still have deleterious consequences for the host due to the production of toxic molecules [120]. 
Overall, the diversity of microbial life in CF airways is now appreciated; however, the understanding of the dynamic nature of the lung microbiome and environment remains incomplete. At a cellular level, A. fumigatus-P. aeruginosa interactions inside the CF lung appear highly complex and are regulated by numerous external environmental factors. Determining the exact type of interactions that occur in each phase of disease will be fundamental to devise novel and/or optimised treatment strategies that can help to maintain lung function. Progressive loss of lung function caused by repeated pulmonary infections is the major cause of death in CF patients $[149,150]$. Therefore, if further research were to confirm that pathogen growth is enhanced in combined infection, combinatorial treatment with drugs that have a synergistic or dual effect would be indicated. In this respect, some new azoles have been described to have anti-P. aeruginosa activity [151] and some antibacterial drugs have direct antifungal activity [152,153] and/or synergise with common antifungals [154-157]. In contrast, if the major effect of the interaction were to trigger secretion of a toxic compound, a virulence blocker would be beneficial. For example, inhibitors of the P. aeruginosa elastase virulence factor, which as mentioned above is upregulated in the presence of $A$. fumigatus [145], have been reported [158-160].

In conclusion, even if our understanding of the interaction between P. aeruginosa and A. fumigatus has advanced significantly in the last few years, further studies employing more physiological models that factor in the complexity of the CF lung are needed to determine the exact interaction that these two pathogens undergo during combined infection. Such accurately modelling for combined infection has proved challenging thus far.

Author Contributions: J.A. and S.G. conceived this manuscript and assisted with manuscript preparation and editing. E.B. performed the bibliography review, drafting and editing of the manuscript. All authors have read and agreed to the published version of the manuscript.

Funding: S.G. was co-funded by the NIHR Manchester Biomedical Research Centre and a NC3Rs Training Fellowship (NC/P002390/1). J.A. is recipient of an MRC Career Development Award (MR/N008707/1).

Conflicts of Interest: In the past 5 years SG has received research funds from Pfizer and has been a council member of the International Society of Human and Animal Mycology (ISHAM). All other authors declare no conflicts of interest.

\section{References}

1. Davies, J.C.; Ebdon, A.M.; Orchard, C. Recent advances in the management of cystic fibrosis. Arch. Dis. Child. 2014, 99, 1033-1036. [CrossRef]

2. Cystic Fibrosis Trust. UK Cystic Fibrosis Registry Annual Data Report 2018. Available online: https: //www.cysticfibrosis.org.uk (accessed on 31 July 2019).

3. Bhagirath, A.Y.; Li, Y.; Somayajula, D.; Dadashi, M.; Badr, S.; Duan, K. Cystic fibrosis lung environment and Pseudomonas aeruginosa infection. BMC Pulm. Med. 2016, 16, 174. [CrossRef] [PubMed]

4. Andersen, D.H. Cystic fibrosis of the pancreas and its relation to celiac disease. Am. J. Dis. Child. 1938, 56, 344. [CrossRef]

5. Elborn, J.S. Cystic fibrosis. Lancet 2016, 388, 2519-2531. [CrossRef]

6. Cohen-Cymberknoh, M.; Shoseyov, D.; Kerem, E. Managing cystic fibrosis. Am. J. Respir. Crit. Care Med. 2011, 183, 1463-1471. [CrossRef]

7. Chmiel, J.F.; Konstan, M.W.; Elborn, J.S. Antibiotic and anti-inflammatory therapies for cystic fibrosis. Cold Spring Harb. Perspect. Med. 2013, 3, a009779. [CrossRef] [PubMed]

8. Cantin, A.; Hartl, M.; Konstan, M.W.; Chmiel, J.F. Inflammation in cystic fibrosis lung disease: Pathogenesis and therapy. J. Cyst. Fibros. 2015, 14, 419-430. [CrossRef]

9. Davis, P.B. Cystic Fibrosis Since 1938. Am. J. Respir. Crit. Care Med. 2006, 173, 475-482. [CrossRef]

10. National Centre for Biotechnology Information Gene. Cftr Cf Transmembrane Conductance Regulator [Homo Sapiens (Human)]. Available online: https://www.ncbi.nlm.nih.gov/ (accessed on 31 July 2019).

11. Viart, V.; Bergougnoux, A.; Bonini, J.; Varilh, J.; Chiron, R.; Tabary, O.; Molinari, N.; Claustres, M.; Taulan-Cadars, M. Transcription factors and miRNAs that regulate fetal to adult CFTR expression change are new targets for cystic fibrosis. Eur. Respir. J. 2014, 45, 116-128. [CrossRef] 
12. Hwang, T.C.; Sheppard, D.N. Gating of the CFTR Cl- channel by ATP-driven nucleotide-binding domain dimerisation. J. Physiol. 2009, 587, 2151-2161. [CrossRef]

13. Ji, H.L.; Chalfant, M.L.; Jovov, B.; Lockhart, J.P.; Parker, S.B.; Fuller, C.; Stanton, B.A.; Benos, D.J. The cytosolic termini of the beta- and gamma-ENaC subunits are involved in the functional interactions between cystic fibrosis transmembrane conductance regulator and epithelial sodium channel. J. Biol. Chem. 2000, 275, 27947-27956. [PubMed]

14. Nagel, G.; Szellas, T.; Riordan, J.R.; Friedrich, T.; Hartung, K. Non-specific activation of the epithelial sodium channel by the CFTR chloride channel. EMBO Rep. 2001, 2, 249-254. [CrossRef] [PubMed]

15. Leroy, C.; Privé, A.; Bourret, J.C.; Berthiaume, Y.; Ferraro, P.; Brochiero, E. Regulation of ENaC and CFTR expression with $\mathrm{K}+$ channel modulators and effect on fluid absorption across alveolar epithelial cells. Am. J. Physiol. Cell. Mol. Physiol. 2006, 291, L1207-L1219. [CrossRef] [PubMed]

16. Lu, M.; Leng, Q.; Egan, M.E.; Caplan, M.J.; Boulpaep, E.L.; Giebisch, G.H.; Hebert, S.C. CFTR is required for PKA-regulated ATP sensitivity of Kir1.1 potassium channels in mouse kidney. J. Clin. Investig. 2006, 116, 797-807. [CrossRef]

17. Wang, J.; Haanes, K.A.; Novak, I. Purinergic regulation of CFTR and Ca2 ${ }^{+}$-activated $\mathrm{Cl}^{-}$channels and $\mathrm{K}^{+}$ channels in human pancreatic duct epithelium. Am. J. Physiol. Physiol. 2013, 304, C673-C684. [CrossRef]

18. Borowitz, U. CFTR, bicarbonate, and the pathophysiology of cystic fibrosis. Pediatr. Pulmonol. 2015, 50, S24-S30. [CrossRef]

19. Gabriel, S.E.; Clarke, L.L.; Boucher, R.C.; Stutts, M.J. CFTR and outward rectifying chloride channels are distinct proteins with a regulatory relationship. Nature 1993, 363, 263-266. [CrossRef]

20. Fischer, H.; Illek, B.; Sachs, L.; Finkbeiner, W.E.; Widdicombe, J.H. CFTR and calcium-activated chloride channels in primary cultures of human airway gland cells of serous or mucous phenotype. Am. J. Physiol. Cell. Mol. Physiol. 2010, 299, L585-L594. [CrossRef]

21. Mall, M.A.; Galietta, L. Targeting ion channels in cystic fibrosis. J. Cyst. Fibros. 2015, 14, 561-570. [CrossRef]

22. Cystic Fibrosis Genetic Analysis Consortium. Cystic Fibrosis Mutation Database. Available online: www.genet.sickkids.on.ca/cftr (accessed on 5 July 2019).

23. Castellani, C.; Cuppens, H.; Macek, M., Jr.; Cassiman, J.J.; Kerem, E.; Durie, P.; Tullis, E.; Assael, B.M.; Bombieri, C.; Brown, A.; et al. Consensus on the use and interpretation of cystic fibrosis mutation analysis in clinical practice. J. Cyst. Fibros. 2008, 7, 179-196. [CrossRef]

24. Vernon, R.M.; Chong, P.A.; Lin, H.; Yang, Z.; Zhou, Q.; Aleksandrov, A.A.; Dawson, J.E.; Riordan, J.R.; Brouillette, C.G.; Thibodeau, P.H.; et al. Stabilization of a nucleotide-binding domain of the cystic fibrosis transmembrane conductance regulator yields insight into disease-causing mutations. J. Biol. Chem. 2017, 292, 14147-14164. [CrossRef]

25. Boyle, M.P.; De Boeck, K. A new era in the treatment of cystic fibrosis: Correction of the underlying CFTR defect. Lancet Respir. Med. 2013, 1, 158-163. [CrossRef]

26. Bono-Neri, F.; Romano, C.; Isedeh, A. Cystic fibrosis: Advancing along the continuum. J. Pediatr. Health Care 2019, 33, 242-254. [CrossRef] [PubMed]

27. O'Sullivan, B.P.; Freedman, S.D. Cystic fibrosis. Lancet 2009, 373, 1891-1904. [CrossRef]

28. Lao, O.; Andrés, A.M.; Mateu, E.; Bertranpetit, J.; Calafell, F.; Andr, A.M. Spatial patterns of cystic fibrosis mutation spectra in European populations. Eur. J. Hum. Genet. 2003, 11, 385-394. [CrossRef] [PubMed]

29. Lewis, H.A.; Zhao, X.; Wang, C.; Sauder, J.M.; Rooney, I.; Noland, B.W.; Lorimer, D.; Kearins, M.C.; Conners, K.; Condon, B.; et al. Impact of the $\Delta$ F508 mutation in first nucleotide-binding domain of human cystic fibrosis transmembrane conductance regulator on domain folding and structure. J. Biol. Chem. 2004, 280, 1346-1353. [CrossRef]

30. Protasevich, I.; Yang, Z.; Wang, C.; Atwell, S.; Zhao, X.; Emtage, S.; Wetmore, D.; Hunt, J.F.; Brouillette, C.G. Thermal unfolding studies show the disease causing F508del mutation in CFTR thermodynamically destabilizes nucleotide-binding domain 1. Protein Sci. 2010, 19, 1917-1931. [CrossRef]

31. Du, K.; Lukacs, G.L. Cooperative assembly and misfolding of CFTR domains in vivo. Mol. Biol. Cell 2009, 20, 1903-1915. [CrossRef]

32. Fernandez, E.F.; De Santi, C.; De Rose, V.; Greene, C.M. CFTR dysfunction in cystic fibrosis and chronic obstructive pulmonary disease. Expert Rev. Respir. Med. 2018, 12, 483-492. [CrossRef]

33. Malhotra, S.; Hayes, D.; Wozniak, D.J. Cystic fibrosis and Pseudomonas aeruginosa: The Host-microbe interface. Clin. Microbiol. Rev. 2019, 32. [CrossRef] 
34. Sergeev, V.; Chou, F.Y.; Lam, G.Y.; Hamilton, C.M.; Wilcox, P.G.; Quon, B.S. The extrapulmonary effects of cystic fibrosis transmembrane conductance regulator modulators in cystic fibrosis. Ann. Am. Thorac. Soc. 2020, 17, 147-154. [CrossRef]

35. Moran, A.; Dunitz, J.; Nathan, B.; Saeed, A.; Holme, B.; Thomas, W. Cystic fibrosis-Related diabetes: Current trends in prevalence, incidence, and mortality. Diabetes Care 2009, 32, 1626-1631. [CrossRef]

36. Harris, W.T.; Kirk, K.L. CFTR and cystic fibrosis. In Ion Channels and Transporters of Epithelia in Health and Disease; Springer Science and Business Media LLC: Berlin, Germany, 2015; pp. 519-552.

37. Graeber, S.Y.; Zhou-Suckow, Z.; Schatterny, J.; Hirtz, S.; Boucher, R.C.; Mall, M.A. Hypertonic saline is effective in the prevention and treatment of mucus obstruction, but not airway inflammation, in mice with chronic obstructive lung disease. Am. J. Respir. Cell Mol. Biol. 2013, 49, 410-417. [CrossRef]

38. Worlitzsch, D.; Tarran, R.; Ulrich, M.; Schwab, U.; Cekici, A.; Meyer, K.C.; Birrer, P.; Bellon, G.; Berger, J.; Weiss, T.; et al. Effects of reduced mucus oxygen concentration in airway pseudomonas infections of cystic fibrosis patients. J. Clin. Investig. 2002, 3, 317-325. [CrossRef]

39. Pezzulo, A.A.; Tang, X.X.; Hoegger, M.J.; Abou Alaiwa, M.H.; Ramachandran, S.; Moninger, T.O.; Karp, P.H.; Wohlford-Lenane, C.L.; Haagsman, H.P.; van Eijk, M.; et al. Reduced airway surface ph impairs bacterial killing in the porcine cystic fibrosis lung. Nature 2012, 487, 109-113. [CrossRef]

40. Berkebile, A.R.; McCray, P.B. Effects of airway surface liquid $\mathrm{pH}$ on host defense in cystic fibrosis. Int. J. Biochem. Cell Biol. 2014, 52, 124-129. [CrossRef]

41. Song, Y.; Salinas, D.; Nielson, D.; Verkman, A.S. Hyperacidity of secreted fluid from submucosal glands in early cystic fibrosis. Am. J. Physiol. Physiol. 2006, 290, C741-C749. [CrossRef]

42. Stoltz, D.; Meyerholz, D.K.; Welsh, M.J. Origins of cystic fibrosis lung disease. N. Engl. J. Med. 2015, 372, 351-362. [CrossRef] [PubMed]

43. Xie, Y.; Ostedgaard, L.; Alaiwa, M.H.A.; Lu, L.; Fischer, A.J.; Stoltz, D.A. Mucociliary transport in healthy and cystic fibrosis pig airways. Ann. Am. Thorac. Soc. 2018, 15, S171-S176. [CrossRef]

44. Gifford, A.M.; Chalmers, J.D. The role of neutrophils in cystic fibrosis. Curr. Opin. Hematol. 2014, $21,16-22$. [CrossRef]

45. Guan, X.; Hou, Y.; Sun, F.; Yang, Z.; Li, C. Dysregulated chemokine signaling in cystic fibrosis lung disease: A Potential therapeutic target. Curr. Drug Targets 2016, 17, 1535-1544. [CrossRef]

46. Castellani, S.; D’Oria, S.; Diana, A.; Polizzi, A.M.; Di Gioia, S.; Mariggiò, M.A.; Guerra, L.; Favia, M.; Vinella, A.; Leonetti, G.; et al. G-CSF and GM-CSF modify neutrophil functions at concentrations found in cystic fibrosis. Sci. Rep. 2019, 9, 12937. [CrossRef]

47. Colombo, C.; Costantini, D.; Rocchi, A.; Cariani, L.; Garlaschi, M.L.; Tirelli, S.; Calori, G.; Copreni, E.; Conese, M. Cytokine levels in sputum of cystic fibrosis patients before and after antibiotic therapy. Pediatr. Pulmonol. 2005, 40, 15-21. [CrossRef]

48. Zaman, M.M.; Gelrud, A.; Junaidi, O.; Regan, M.M.; Warny, M.; Shea, J.C.; Kelly, C.; O'Sullivan, B.P.; Freedman, S.D. Interleukin 8 secretion from monocytes of subjects heterozygous for the deltaf508 cystic fibrosis transmembrane conductance regulator gene mutation is altered. Clin. Diagn. Lab. Immunol. 2004, 11, 819-824. [CrossRef]

49. Freedman, S.D.; Blanco, P.G.; Zaman, M.M.; Shea, J.C.; Ollero, M.; Hopper, I.K.; Weed, D.A.; Gelrud, A.; Regan, M.M.; Laposata, M.; et al. Association of cystic fibrosis with abnormalities in fatty acid metabolism. N. Engl. J. Med. 2004, 350, 560-569. [CrossRef]

50. Karp, C.L.; Flick, L.M.; Park, K.W.; Softic, S.; Greer, T.M.; Keledjian, R.; Yang, R.; Uddin, J.; Guggino, W.B.; Atabani, S.F.; et al. Defective lipoxin-mediated anti-inflammatory activity in the cystic fibrosis airway. Nat. Immunol. 2004, 5, 388-392. [CrossRef]

51. Cohen-Cymberknoh, M.; Kerem, E.; Ferkol, T.; Elizur, A. Airway inflammation in cystic fibrosis: Molecular mechanisms and clinical implications. Thorax 2013, 68, 1157-1162. [CrossRef]

52. Hartl, D.; Gaggar, A.; Bruscia, E.; Hector, A.; Marcos, V.; Jung, A.; Greene, C.M.; McElvaney, G.; Mall, M.; Doring, G. Innate immunity in cystic fibrosis lung disease. J. Cyst. Fibros. 2012, 11, 363-382. [CrossRef]

53. Elborn, S.; Vallieres, E. Cystic fibrosis gene mutations: Evaluation and assessment of disease severity. Adv. Genom. Genet. 2014, 4, 161-172. [CrossRef]

54. Dickson, R.P.; Huffnagle, G.B. The lung microbiome: New principles for respiratory bacteriology in health and disease. PLOS Pathog. 2015, 11, e1004923. [CrossRef] 
55. Surette, M.G. The cystic fibrosis lung microbiome. Ann. Am. Thorac. Soc. 2014, 11, S61-S65. [CrossRef] [PubMed]

56. Marsland, B.J.; Gollwitzer, E.S. Host-microorganism interactions in lung diseases. Nat. Rev. Immunol. 2014, 14, 827-835. [CrossRef] [PubMed]

57. Krüger, W.; Vielreicher, S.; Kapitan, M.; Jacobsen, I.D.; Niemiec, M.J. Fungal-bacterial interactions in health and disease. Pathogens 2019, 8, 70. [CrossRef] [PubMed]

58. Huang, Y.J.; Lynch, S.V. The emerging relationship between the airway microbiota and chronic respiratory disease: Clinical implications. Expert Rev. Respir. Med. 2011, 5, 809-821. [CrossRef] [PubMed]

59. Huang, Y.J.; Lipuma, J.J. The microbiome in cystic fibrosis. Clin. Chest Med. 2016, 37, 59-67. [CrossRef]

60. Bevivino, A.; Bacci, G.; Drevinek, P.; Nelson, M.T.; Hoffman, L.; Mengoni, A. Deciphering the ecology of cystic fibrosis bacterial communities: Towards systems-level integration. Trends Mol. Med. 2019, 25, 1110-1122. [CrossRef]

61. Wylie, K.M.; Weinstock, G.M.; Storch, G.A. Emerging view of the human virome. Transl. Res. 2012, 160, 283-290. [CrossRef]

62. Billard, L.; Le Berre, R.; Pilorgé, L.; Payan, C.; Héry-Arnaud, G.; Vallet, S. Viruses in cystic fibrosis patients' airways. Crit. Rev. Microbiol. 2017, 43, 690-708. [CrossRef]

63. Kiedrowski, M.R.; Bomberger, J.M. Viral-bacterial co-infections in the cystic fibrosis respiratory tract. Front. Immunol. 2018, 9, 3067. [CrossRef]

64. Rosenfeld, M.; Ramsey, B.W.; Gibson, R.L. Pseudomonas acquisition in young patients with cystic fibrosis: Pathophysiology, diagnosis, and management. Curr. Opin. Pulm. Med. 2003, 9, 492-497. [CrossRef]

65. Cystic Fibrosis Foundation. US 2018 Patient Registry Annual Data Report. Available online: https: //www.cff.org (accessed on 24 July 2020).

66. Stutman, H.R.; Lieberman, J.M.; Nussbaum, E.; Marks, M.I. Antibiotic prophylaxis in infants and young children with cystic fibrosis: A randomized controlled trial. J. Pediatr. 2002, 140, 299-305. [CrossRef]

67. Ratjen, F.; Comes, G.; Paul, K.; Posselt, H.; Wagner, T.; Harms, K. Effect of continuous antistaphylococcal therapy on the rate of P. aeruginosa acquisition in patients with cystic fibrosis. Pediatr. Pulmonol. 2001, 31, 13-16. [CrossRef]

68. Treggiari, M.M.; Rosenfeld, M.; Retsch-Bogart, G.; Gibson, R.; Ramsey, B. Approach to eradication of initial Pseudomonas aeruginosa infection in children with cystic fibrosis. Pediatr. Pulmonol. 2007, 42, 751-756. [CrossRef] [PubMed]

69. Stuart, B.; Lin, J.H.; Mogayzel, J.P.J. Early eradication of Pseudomonas aeruginosa in patients with cystic fibrosis. Paediatr. Respir. Rev. 2010, 11, 177-184. [CrossRef] [PubMed]

70. Hewer, S.C.L.; Smyth, A.R. Antibiotic strategies for eradicating Pseudomonas aeruginosa in people with cystic fibrosis. Cochrane Database Syst. Rev. 2017, 2017, CD004197. [CrossRef]

71. Zhao, J.; Schloss, P.D.; Kalikin, L.M.; Carmody, L.A.; Foster, B.K.; Petrosino, J.F.; Cavalcoli, J.D.; VanDevanter, D.R.; Murray, S.; Li, J.Z.; et al. Decade-long bacterial community dynamics in cystic fibrosis airways. Proc. Natl. Acad. Sci. USA 2012, 109, 5809-5814. [CrossRef]

72. Martiniano, S.L.; Nick, J.A.; Daley, C.L. Nontuberculous mycobacterial infections in cystic fibrosis. Clin. Chest Med. 2016, 37, 83-96. [CrossRef]

73. Lamoureux, C.; Guilloux, C.-A.; Beauruelle, C.; Jolivet-Gougeon, A.; Héry-Arnaud, G. Anaerobes in cystic fibrosis patients' airways. Crit. Rev. Microbiol. 2019, 45, 103-117. [CrossRef]

74. Jones, A.M. Anaerobic bacteria in cystic fibrosis: Pathogens or harmless commensals? Thorax 2011, 66, 558-559. [CrossRef]

75. Armstead, J.; Morris, J.; Denning, D.W. Multi-country estimate of different manifestations of aspergillosis in cystic fibrosis. PLoS ONE 2014, 9, e98502. [CrossRef]

76. Weaver, D.; Gago, S.; Bromley, M.; Bowyer, P. The human lung mycobiome in chronic respiratory disease: Limitations of methods and our current understanding. Curr. Fungal Infect. Rep. 2019, 13, 109-119. [CrossRef]

77. Engel, T.G.; Slabbers, L.; De Jong, C.; Melchers, W.J.; Hagen, F.; Verweij, P.E.; Merkus, P.; Meis, J.F. Prevalence and diversity of filamentous fungi in the airways of cystic fibrosis patients-A Dutch, multicentre study. J. Cyst. Fibros. 2019, 18, 221-226. [CrossRef] [PubMed]

78. Williams, C.; Ranjendran, R.; Ramage, G. Pathogenesis of Fungal Infections in Cystic Fibrosis. Curr. Fungal Infect. Rep. 2016, 10, 163-169. [CrossRef] [PubMed] 
79. King, J.; Brunel, S.F.; Warris, A. Aspergillus infections in cystic fibrosis. J. Infect. 2016, 72, S50-S55. [CrossRef] [PubMed]

80. Lipuma, J.J. The changing microbial epidemiology in cystic fibrosis. Clin. Microbiol. Rev. 2010, 23, $299-323$. [CrossRef]

81. Folkesson, A.; Jelsbak, L.; Yang, L.; Johansen, H.K.; Ciofu, O.; Høiby, N.; Molin, S. Adaptation of Pseudomonas aeruginosa to the cystic fibrosis airway: An evolutionary perspective. Nat. Rev. Genet. 2012, 10, 841-851. [CrossRef] [PubMed]

82. Burns, J.L.; Gibson, R.L.; McNamara, S.; Yim, D.; Emerson, J.; Rosenfeld, M.; Hiatt, P.; McCoy, K.; Castile, R.; Smith, A.L.; et al. Longitudinal assessment of Pseudomonas aeruginosa in young children with cystic fibrosis. J. Infect. Dis. 2001, 183, 444-452. [CrossRef]

83. Reece, E.; Segurado, R.; Jackson, A.D.; McClean, S.; Renwick, J.; Greally, P. Co-colonisation with Aspergillus fumigatus and Pseudomonas aeruginosa is associated with poorer health in cystic fibrosis patients: An Irish registry analysis. BMC Pulm. Med. 2017, 17, 70. [CrossRef]

84. Gonçalves-De-Albuquerque, C.F.; Silva, A.R.; Burth, P.; Rocco, P.R.M.; Castro-Faria, M.V.; Castro-Faria-Neto, H.C. Possible mechanisms of Pseudomonas aeruginosa-associated lung disease. Int. J. Med. Microbiol. 2016, 306, 20-28. [CrossRef]

85. Diaz, M.H.; Shaver, C.M.; King, J.D.; Musunuri, S.; Kazzaz, J.A.; Hauser, A.R. Pseudomonas aeruginosa induces localized immunosuppression during pneumonia. Infect. Immun. 2008, 76, 4414-4421. [CrossRef]

86. Manago, A.; Becker, K.A.; Carpinteiro, A.; Wilker, B.; Soddemann, M.; Seitz, A.P.; Edwards, M.J.; Grassmé, H.; Szabò, I.; Gulbins, E. Pseudomonas aeruginosa pyocyanin induces neutrophil death via mitochondrial reactive oxygen species and mitochondrial acid sphingomyelinase. Antioxid. Redox Sign. 2015, 22, 1097-1110. [CrossRef]

87. Laarman, A.J.; Bardoel, B.W.; Ruyken, M.; Fernie, J.; Milder, F.J.; Van Strijp, J.A.; Rooijakkers, S.H.M. Pseudomonas aeruginosa alkaline protease blocks complement activation via the classical and lectin pathways. J. Immunol. 2011, 188, 386-393. [CrossRef] [PubMed]

88. Hogardt, M.; Heesemann, J. Microevolution of Pseudomonas aeruginosa to a chronic pathogen of the cystic fibrosis lung. Curr. Top Microbiol. Immunol. 2013, 358, 91-118. [PubMed]

89. Mayer-Hamblett, N.; Rosenfeld, M.; Gibson, R.L.; Ramsey, B.W.; Kulasekara, H.D.; Retsch-Bogart, G.Z.; Morgan, W.; Wolter, D.J.; Pope, C.E.; Houston, L.S.; et al. Pseudomonas aeruginosa in vitro phenotypes distinguish cystic fibrosis infection stages and outcomes. Am. J. Respir. Crit. Care Med. 2014, 190, 289-297. [CrossRef] [PubMed]

90. Cigana, C.; Lore', N.I.; Riva, C.; De Fino, I.; Spagnuolo, L.; Sipione, B.; Rossi, G.; Nonis, A.; Cabrini, G.; Bragonzi, A. Tracking the immunopathological response to Pseudomonas aeruginosa during respiratory infections. Sci. Rep. 2016, 6, 21465. [CrossRef]

91. Hogardt, M.; Heesemann, J. Adaptation of Pseudomonas aeruginosa during persistence in the cystic fibrosis lung. Int. J. Med. Microbiol. 2010, 300, 557-562. [CrossRef] [PubMed]

92. Winstanley, C.; O’Brien, S.; Brockhurst, M.A. Pseudomonas aeruginosa evolutionary adaptation and diversification in cystic fibrosis chronic lung infections. Trends Microbiol. 2016, 24, 327-337. [CrossRef] [PubMed]

93. Vandeplassche, E.; Sass, A.M.; Lemarcq, A.; Dandekar, A.A.; Coenye, T.; Crabbé, A. In vitro evolution of Pseudomonas aeruginosa AA2 biofilms in the presence of cystic fibrosis lung microbiome members. Sci. Rep. 2019, 9, 12814-12859. [CrossRef]

94. Bjarnsholt, T.; Jensen, P.Ø.; Fiandaca, M.J.; Pedersen, J.; Hansen, C.R.; Andersen, C.B.; Pressler, T.; Givskov, M.; Høiby, N. Pseudomonas aeruginosa biofilms in the respiratory tract of cystic fibrosis patients. Pediatr. Pulmonol. 2009, 44, 547-558. [CrossRef]

95. Olivares, E.; Badel-Berchoux, S.; Provot, C.; Prévost, G.; Bernardi, T.; Jehl, F. Clinical impact of antibiotics for the treatment of Pseudomonas aeruginosa biofilm infections. Front. Microbiol. 2020, 10. [CrossRef]

96. McDaniel, C.T.; Panmanee, W.; Hassett, D.J. An overview of infections in cystic fibrosis airways and the role of environmental conditions on Pseudomonas aeruginosa biofilm formation and viability. In Cystic Fibrosis in the Light of New Research; IntechOpen: London, UK, 2015.

97. Li, Z.; Kosorok, M.R.; Farrell, P.M.; Laxova, A.; West, S.E.H.; Green, C.G.; Collins, J.; Rock, M.J.; Splaingard, M.L. Longitudinal development of mucoid Pseudomonas aeruginosa infection and lung disease progression in children with cystic fibrosis. JAMA 2005, 293, 581-588. [CrossRef] [PubMed] 
98. Leid, J.G.; Willson, C.J.; Shirtliff, M.E.; Hassett, D.J.; Parsek, M.R.; Jeffers, A.K. The exopolysaccharide alginate protects Pseudomonas aeruginosa biofilm bacteria from IFN-gamma-mediated macrophage killing. J. Immunol. 2005, 175, 7512-7518. [CrossRef] [PubMed]

99. Young, R.L.; Malcolm, K.C.; Kret, J.E.; Caceres, S.M.; Poch, K.R.; Nichols, D.P.; Taylor-Cousar, J.L.; Saavedra, M.T.; Randell, S.H.; Vasil, M.L.; et al. Neutrophil extracellular trap (NET)-mediated killing of Pseudomonas aeruginosa: Evidence of acquired resistance within the CF airway, independent of CFTR. PLoS ONE 2011, 6, e23637. [CrossRef] [PubMed]

100. Pier, G.B.; Coleman, F.; Grout, M.; Franklin, M.; Ohman, D.E. Role of alginate o acetylation in resistance of mucoid Pseudomonas aeruginosa to opsonic phagocytosis. Infect. Immun. 2001, 69, 1895-1901. [CrossRef]

101. Malhotra, S.; Limoli, D.H.; English, A.E.; Parsek, M.R.; Wozniak, D.J. Mixed communities of mucoid and nonmucoid Pseudomonas aeruginosa exhibit enhanced resistance to host antimicrobials. mBio 2018, 9, e00275-18. [CrossRef]

102. Goltermann, L.; Tolker-Nielsen, T. Importance of the exopolysaccharide matrix in antimicrobial tolerance of Pseudomonas aeruginosa aggregates. Antimicrob. Agents Chemother. 2017, 61, e02696-16. [CrossRef]

103. Van De Veerdonk, F.L.; Gresnigt, M.S.; Romani, L.; Netea, M.G.; Latgé, J.P. Aspergillus fumigatus morphology and dynamic host interactions. Nat. Rev. Genet. 2017, 15, 661-674. [CrossRef]

104. Ballard, E.; Melchers, W.J.G.; Zoll, J.; Brown, A.J.P.; Verweij, P.E.; Warris, A. In-host microevolution of Aspergillus fumigatus: A phenotypic and genotypic analysis. Fungal Genet. Biol. 2018, 113, 1-13. [CrossRef]

105. Warris, A.; Verweij, P.E. Clinical implications of environmental sources for Aspergillus. Med. Mycol. 2005, 43, 59-65. [CrossRef]

106. Gago, S.; Denning, D.W.; Bowyer, P. Pathophysiological aspects of Aspergillus colonization in disease. Med. Mycol. 2019, 57, S219-S227. [CrossRef]

107. Kosmidis, C.; Denning, D.W. Republished: The clinical spectrum of pulmonary aspergillosis. Postgrad. Med. J. 2015, 91, 403-410. [CrossRef]

108. Paulussen, C.; Hallsworth, J.E.; Álvarez-Pérez, S.; Nierman, W.C.; Hamill, P.G.; Blain, D.; Rediers, H.; Lievens, B. Ecology of aspergillosis: Insights into the pathogenic potency of Aspergillus fumigatus and some other Aspergillus species. Microb. Biotechnol. 2016, 10, 296-322. [CrossRef]

109. Bongomin, F.; Gago, S.; Oladele, R.O.; Denning, D.W. Global and multi-national prevalence of fungal diseases-Estimate precision. J. Fungi 2017, 3, 57. [CrossRef]

110. Escobar, N.; Ordonez, S.R.; Wösten, H.A.B.; Haas, P.J.A.; De Cock, H.; Haagsman, H.P. Hide, keep quiet, and keep low: Properties that make Aspergillus fumigatus a successful lung pathogen. Front. Microbiol. 2016, 7, 438. [CrossRef]

111. Wiesner, D.L.; Klein, B.S. Lung epithelium: Barrier immunity to inhaled fungi and driver of fungal-associated allergic asthma. Curr. Opin. Microbiol. 2017, 40, 8-13. [CrossRef]

112. Overton, N.; Gago, S.; Bowyer, P. Immunogenetics of chronic and allergic aspergillosis. In Immunogenetics of Fungal Diseases; Springer Science and Business Media LLC: Berlin, Germany, 2017; Volume 108, pp. $153-171$.

113. McCormick, A.; Heesemann, L.; Wagener, J.; Marcos, V.; Hartl, D.; Loeffler, J.; Heesemann, J.; Ebel, F. NETs formed by human neutrophils inhibit growth of the pathogenic mold Aspergillus fumigatus. Microbes Infect. 2010, 12, 928-936. [CrossRef]

114. Moss, R.B. Treating allergic bronchopulmonary aspergillosis: The way forward. Eur. Respir. J. 2016, 47, 385-387. [CrossRef]

115. Baxter, C.; Dunn, G.; Jones, A.M.; Webb, K.; Gore, R.; Richardson, M.D.; Denning, D.W. Novel immunologic classification of aspergillosis in adult cystic fibrosis. J. Allergy Clin. Immunol. 2013, 132, 560-566.e10. [CrossRef]

116. Agarwal, R.; Chakrabarti, A.; Shah, A.; Gupta, D.; Meis, J.F.G.M.; Guleria, R.; Moss, R.; Denning, D.W. ABPA complicating asthma ISHAM working group Allergic bronchopulmonary aspergillosis: Review of literature and proposal of new diagnostic and classification criteria. Clin. Exp. Allergy 2013, 43, 850-873. [CrossRef]

117. Denning, D.W.; Pashley, C.H.; Hartl, D.; Wardlaw, A.J.; Godet, C.; Del Giacco, S.; Delhaes, L.; Sergejeva, S. Fungal allergy in asthma-state of the art and research needs. Clin. Transl. Allergy 2014, 4, 14. [CrossRef]

118. Brandt, C.; Roehmel, J.; Rickerts, V.; Melichar, V.; Niemann, N.; Schwarz, C. Aspergillus Bronchitis in Patients with Cystic Fibrosis. Mycopathologia 2017, 183, 61-69. [CrossRef]

119. Chrdle, A.; Mustakim, S.; Bright-Thomas, R.J.; Baxter, C.G.; Felton, T.; Denning, D.W. Aspergillus bronchitis without significant immunocompromise. Ann. Acad. Sci. 2012, 1272, 73-85. [CrossRef] [PubMed] 
120. Zhao, J.; Cheng, W.; He, X.; Liu, Y. The co-colonization prevalence of Pseudomonas aeruginosa and Aspergillus fumigatus in cystic fibrosis: A systematic review and meta-analysis. Microb. Pathog. 2018, 125, $122-128$. [CrossRef] [PubMed]

121. Paugam, A.; Baixench, M.T.; Demazes-Dufeu, N.; Burgel, P.R.; Sauter, E.; Kanaan, R.; Dusser, D.; Dupouy-Camet, J.; Hubert, D. Characteristics and consequences of airway colonization by filamentous fungi in 201 adult patients with cystic fibrosis in France. Med. Mycol. 2010, 48, 32-36. [CrossRef] [PubMed]

122. Bakare, N.; Rickerts, V.; Bargon, J.; Just-Nübling, G. Prevalence of Aspergillus fumigatus and other fungal species in the sputum of adult patients with cystic fibrosis. Mycoses 2003, 46, 19-23. [CrossRef]

123. Granchelli, A.M.; Adler, F.R.; Keogh, R.H.; Kartsonaki, C.; Cox, D.R.; Liou, T.G. Microbial interactions in the cystic fibrosis airway. J. Clin. Microbiol. 2018, 56, JCM.00354-18. [CrossRef]

124. Hector, A.; Kirn, T.; Ralhan, A.; Graepler-Mainka, U.; Berenbrinker, S.; Riethmueller, J.; Hogardt, M.; Wagner, M.; Pfleger, A.; Autenrieth, I.; et al. Microbial colonization and lung function in adolescents with cystic fibrosis. J. Cyst. Fibros. 2016, 15, 340-349. [CrossRef]

125. Amin, R.; Dupuis, A.; Aaron, S.D.; Ratjen, F. The effect of chronic infection with Aspergillus fumigatus on lung function and hospitalization in patients with cystic fibrosis. Chest 2010, 137, 171-176. [CrossRef]

126. Briard, B.; Rasoldier, V.; Bomme, P.; ElAouad, N.; Guerreiro, C.; Chassagne, P.; Muszkieta, L.; Latge, J.P.; Mulard, L.; Beauvais, A. Dirhamnolipids secreted from Pseudomonas aeruginosa modify antifungal susceptibility of Aspergillus fumigatus by inhibiting beta1,3 glucan synthase activity. ISME J. 2017, 11, 1578-1591. [CrossRef]

127. Mowat, E.; Rajendran, R.; Williams, C.; McCulloch, E.; Jones, B.; Lang, S.; Ramage, G. Pseudomonas aeruginosa and their small diffusible extracellular molecules inhibit Aspergillus fumigatus biofilm formation. FEMS Microbiol. Lett. 2010, 313, 96-102. [CrossRef]

128. Briard, B.; Bomme, P.; Lechner, B.E.; Mislin, G.L.; Lair, V.; Prevost, M.C.; Latge, J.P.; Haas, H.; Beauvais, A. Pseudomonas aeruginosa manipulates redox and iron homeostasis of its microbiota partner Aspergillus fumigatus via phenazines. Sci. Rep. 2015, 5, 8220. [CrossRef] [PubMed]

129. Zhao, J.; Yu, W. Interaction between Pseudomonas aeruginosa and Aspergillus fumigatus in cystic fibrosis. Peer J. 2018, 6, e5931. [CrossRef]

130. Sass, G.; Nazik, H.; Penner, J.; Shah, H.; Ansari, S.R.; Clemons, K.V.; Groleau, M.C.; Dietl, A.M.; Visca, P.; Haas, H.; et al. Studies of Pseudomonas aeruginosa mutants indicate pyoverdine as the central factor in inhibition of Aspergillus fumigatus biofilm. J. Bacteriol. 2018, 200, e00345-17. [CrossRef] [PubMed]

131. Sass, G.; Nazik, H.; Penner, J.; Shah, H.; Ansari, S.R.; Clemons, K.V.; Groleau, M.C.; Dietl, A.M.; Visca, P.; Haas, H.; et al. Aspergillus-Pseudomonas interaction, relevant to competition in airways. Med Mycol. 2019, 57, S228-S232. [CrossRef] [PubMed]

132. Briard, B.; Mislin, G.L.A.; Latge, J.P.; Beauvais, A. Interactions between Aspergillus fumigatus and pulmonary bacteria: Current state of the field, new data, and future perspective. J. Fungi 2019, 5, 48. [CrossRef]

133. Penner, J.C.; Ferreira, J.A.G.; Secor, P.R.; Sweere, J.M.; Birukova, M.K.; Joubert, L.-M.; Haagensen, J.A.J.; Garcia, O.; Malkovskiy, A.V.; Kaber, G.; et al. Pf4 bacteriophage produced by Pseudomonas aeruginosa inhibits Aspergillus fumigatus metabolism via iron sequestration. Microbiology 2016, 162, 1583-1594. [CrossRef]

134. Reece, E.; Doyle, S.; Greally, P.; Renwick, J.; McClean, S. Aspergillus fumigatus inhibits pseudomonas aeruginosa in co-culture: Implications of a mutually antagonistic relationship on virulence and inflammation in the CF airway. Front. Microbiol. 2018, 9, 1205. [CrossRef]

135. Briard, B.; Heddergott, C.; Latge, J.P. Volatile compounds emitted by Pseudomonas aeruginosa stimulate growth of the fungal pathogen Aspergillus fumigatus. mBio 2016, 7, 00219. [CrossRef]

136. Moree, W.J.; Phelan, V.V.; Wu, C.H.; Bandeira, N.A.G.; Cornett, D.S.; Duggan, B.M.; Dorrestein, P.C. Interkingdom metabolic transformations captured by microbial imaging mass spectrometry. Proc. Natl. Acad. Sci. USA 2012, 109, 13811-13816. [CrossRef]

137. Sass, G.; Ansari, S.R.; Dietl, A.M.; Déziel, E.; Haas, H.; Stevens, D.A. Intermicrobial interaction: Aspergillus fumigatus siderophores protect against competition by Pseudomonas aeruginosa. PLoS ONE 2019, 14, e0216085. [CrossRef]

138. Nazik, H.; Sass, G.; Ansari, S.R.; Ertekin, R.; Haas, H.; Déziel, E.; Stevens, D.A. Novel intermicrobial molecular interaction: Pseudomonas aeruginosa Quinolone Signal (PQS) modulates Aspergillus fumigatus response to iron. Microbiology 2020, 166, 44-55. [CrossRef] 
139. Margalit, A.; Carolan, J.C.; Shehan, D.; Kavanagh, K. The Aspergillus fumigatus secretome alters the proteome of Pseudomonas aeruginosa to stimulate bacterial growth: Implications for co-infection. Mol. Cell. Proteom. 2020, 1-45. [CrossRef]

140. Anand, R.; Clemons, K.V.; Stevens, D.A. Effect of anaerobiasis or hypoxia on Pseudomonas aeruginosa inhibition of Aspergillus fumigatus biofilm. Arch. Microbiol. 2017, 199, 881-890. [CrossRef]

141. Anand, R.; Moss, R.B.; Sass, G.; Banaei, N.; Clemons, K.V.; Martinez, M.; Stevens, D.A. Small colony variants of Pseudomonas aeruginosa display heterogeneity in inhibiting Aspergillus fumigatus biofilm. Mycopathologia 2017, 183, 263-272. [CrossRef]

142. Ferreira, J.A.G.; Penner, J.C.; Moss, R.B.; Haagensen, J.A.J.; Clemons, K.V.; Spormann, A.M.; Nazik, H.; Cohen, K.; Banaei, N.; Carolino, E.; et al. Inhibition of Aspergillus fumigatus and its biofilm by Pseudomonas aeruginosa is dependent on the source, phenotype and growth conditions of the bacterium. PLoS ONE 2015, 10, e0134692. [CrossRef]

143. Scott, J.; Sueiro-Olivares, M.; Ahmed, W.; Heddergott, C.; Zhao, C.; Thomas, R.; Bromley, M.; Latgé, J.-P.; Krappmann, S.; Fowler, S.; et al. Pseudomonas aeruginosa-derived volatile sulfur compounds promote distal Aspergillus fumigatus growth and a synergistic pathogen-pathogen interaction that increases pathogenicity in co-infection. Front. Microbiol. 2019, 10, 2311. [CrossRef]

144. Margalit, A.; Kavanagh, K.; Carolan, J.C. Characterization of the proteomic response of A549 cells following sequential exposure to Aspergillus fumigatus and Pseudomonas aeruginosa. J. Proteome Res. 2019, 19, $279-291$. [CrossRef]

145. Smith, K.; Rajendran, R.; Kerr, S.; Lappin, D.F.; Mackay, W.; Williams, C.; Ramage, G. Aspergillus fumigatus enhances elastase production in Pseudomonas aeruginosa co-cultures. Med. Mycol. 2015, 53, 645-655. [CrossRef]

146. Yonezawa, M.; Sugiyama, H.; Kizawa, K.; Hori, R.; Mitsuyama, J.; Araki, H.; Shimakura, M.; Minami, S.; Watanabe, Y.; Yamaguchi, K. A new model of pulmonary superinfection with Aspergillus fumigatus and Pseudomonas aeruginosa in mice. J. Infect. Chemother. 2000, 6, 155-161. [CrossRef]

147. Mitsuyama, J.; Kizawa, K.; Minami, S.; Watanabe, Y.; Yamaguchi, K. Evaluation of antimicrobial agents using an experimental pulmonary superinfection model with Aspergillus fumigatus and Pseudomonas aeruginosa in leukopenic mice. J. Infect. Chemother. 2003, 9, 144-150. [CrossRef]

148. Shirazi, F.; Ferreira, J.A.G.; Stevens, D.A.; Clemons, K.V.; Kontoyiannis, D.P. Biofilm filtrates of Pseudomonas aeruginosa strains isolated from cystic fibrosis patients inhibit preformed Aspergillus fumigatus biofilms via apoptosis. PLoS ONE 2016, 11, e0150155. [CrossRef]

149. Döring, G.; Flume, P.; Heijerman, H.; Elborn, J.S. Treatment of lung infection in patients with cystic fibrosis: Current and future strategies. J. Cyst. Fibros. 2012, 11, 461-479. [CrossRef]

150. Lyczak, J.B.; Cannon, C.L.; Pier, G.B. Lung infections associated with cystic fibrosis. Clin. Microbiol. Rev. 2002, 15, 194-222. [CrossRef]

151. Khabnadideh, S.; Rezaei, Z.; Ghasemi, Y.; Najafabady, N.M. Antibacterial Activity of Some New Azole Compounds. Anti-Infective Agents 2012, 10, 26-33. [CrossRef]

152. Day, S.; Lalitha, P.; Haug, S.; Fothergill, A.W.; Cevallos, V.; Vijayakumar, R.; Prajna, N.V.; Acharya, N.R.; McLeod, S.D.; Lietman, T.M. Activity of antibiotics against Fusarium; and Aspergillus. Br. J. Ophthalmol. 2009, 93, 116. [CrossRef]

153. Azevedo, M.M.; Teixeira-Santos, R.; Silva, A.P.; Cruz, L.; Ricardo, E.; Pina-Vaz, C.; Rodrigues, A.G. The effect of antibacterial and non-antibacterial compounds alone or associated with antifugals upon fungi. Front. Microbiol. 2015, 6. [CrossRef]

154. Venturini, T.; Al-Hatmi, A.M.S.; Rossato, L.; Azevedo, M.I.; Keller, J.T.; Weiblen, C.; Santurio, J.M.; Alves, S.H. Do antibacterial and antifungal combinations have better activity against clinically relevant Fusarium species? in vitro synergism. Int. J. Antimicrob. Agents 2018, 51, 784-788. [CrossRef] [PubMed]

155. Eldesouky, H.E.; Li, X.; Abutaleb, N.S.; Mohammad, H.; Seleem, M.N. Synergistic interactions of sulfamethoxazole and azole antifungal drugs against emerging multidrug-resistant Candida auris. Int. J. Antimicrob. Agents 2018, 52, 754-761. [CrossRef]

156. Wambaugh, A.; Denham, M.; Ayala, S.T.; Brammer, M.; Stonhill, B.A.; Brown, M. Synergistic and antagonistic drug interactions in the treatment of systemic fungal infections. eLife 2020, 9. [CrossRef]

157. Fiori, A.; Van Dijck, P. Potent synergistic effect of doxycycline with fluconazole against Candida albicans is mediated by interference with iron homeostasis. Antimicrob. Agents Chemother. 2012, 56, 3785. [CrossRef] 
158. Galdino, A.C.M.; Viganor, L.; De Castro, A.A.; Da Cunha, E.F.F.; Mello, T.P.; Mattos, L.M.; Pereira, M.D.; Hunt, M.C.; O'Shaughnessy, M.; Howe, O.; et al. Disarming Pseudomonas aeruginosa virulence by the inhibitory action of 1,10-phenanthroline-5,6-dione-based compounds: Elastase b (lasb) as a chemotherapeutic target. Front. Microbiol. 2019, 10, 1701. [CrossRef]

159. Cathcart, G.R.A.; Quinn, D.; Greer, B.; Harriott, P.; Lynas, J.F.; Gilmore, B.F.; Walker, B. Novel inhibitors of the pseudomonas aeruginosa virulence factor LasB: A potential therapeutic approach for the attenuation of virulence mechanisms in pseudomonal infection. Antimicrob. Agents Chemother. 2011, 55, 2670-2678. [CrossRef] [PubMed]

160. Chatterjee, P.; Sass, G.; Swietnicki, W.; Stevens, D.A. Review of potential pseudomonas weaponry, relevant to the Pseudomonas-Aspergillus interplay, for the mycology community. J. Fungi 2020, 6, 81. [CrossRef] [PubMed]

(C) 2020 by the authors. Licensee MDPI, Basel, Switzerland. This article is an open access article distributed under the terms and conditions of the Creative Commons Attribution (CC BY) license (http://creativecommons.org/licenses/by/4.0/). 